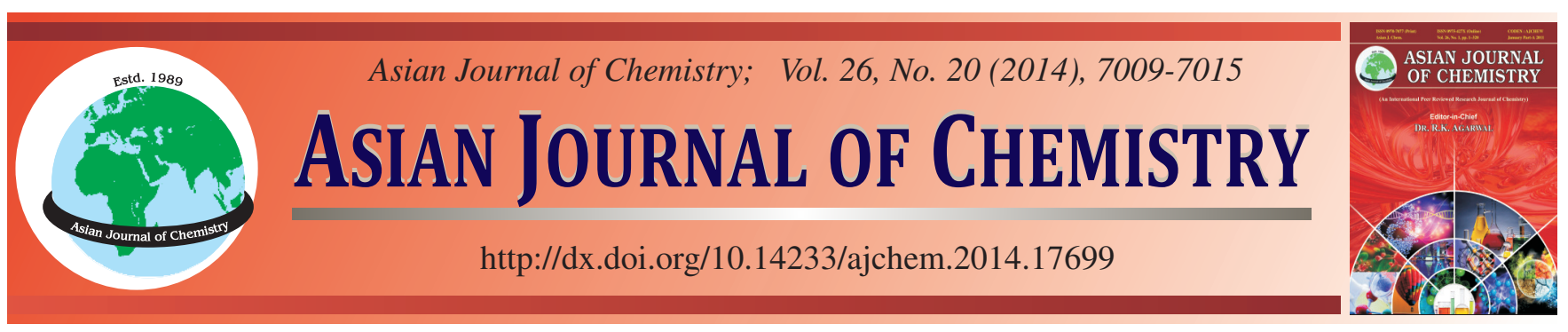

\title{
Antioxidant Activity, Synthesis and Characterization of Schiff Base Ligand 'asasp' and Metal Complexes
}

\author{
Mecit Ozdemir ${ }^{1, *}$ and Mehmet Sonmez ${ }^{2}$
}

${ }^{1}$ Chemistry Department, Faculty of Arts and Science, University of Kilis 7 Aralik, Kilis, Turkey ${ }^{2}$ Chemistry Department, Faculty of Arts and Science, University of Gaziantep, Gaziantep, Turkey

*Corresponding author: Fax: +90 348 8142663; Tel: +90 348 3488142662; E-mail: mecitozdemir@kilis.edu.tr

\begin{abstract}
In the present work, the synthesis and structural characterization of a novel Schiff base ligand derived from 2-acetyl pyridine and L-aspartic acid dimethyl ester and its metal complexes have been reported. All the synthesized compounds were characterized by using various spectral techniques like ESI-MS, FT-IR, ${ }^{1} \mathrm{H}$ NMR, ${ }^{13} \mathrm{C}$ NMR, UV-visible spectra, elemental analysis and ICP-OES analyses. The ligand and metal ions reacted to form in the $2: 1$ or $1: 1(\mathrm{M}: \mathrm{L})$ ratio as found from the elemental analyses and the general stoichiometry was determined $\left[\mathrm{L}(\mathrm{Cu})_{2}(\mathrm{AcO})_{4}\right]$ and $\left[\mathrm{LM}\left(\mathrm{H}_{2} \mathrm{O}\right)_{2}\right] 2 \mathrm{Cl} \cdot \mathrm{nH}_{2} \mathrm{O}$ where $\mathrm{M}=\mathrm{Co}(\mathrm{II}), \mathrm{Ni}(\mathrm{II}), \mathrm{Ni}(\mathrm{II})$ and $\mathrm{L}=$ asasp and $\mathrm{n}=1$ or 2 . On the basis of analytical data, a possible structure for the copper(II) complex is tetrahedral and those for the $\mathrm{Co}(\mathrm{II}), \mathrm{Ni}(\mathrm{II})$ and $\mathrm{Mn}$ (II) complexes are octahedral. The ligand and its metal complexes were tested for their possible antioxidant potentials. Comparison of antioxidant assays were investigated by using two reference molecules, vitamin $\mathrm{C}$ and quercetin. The complexes showed significant activities in these in vitro antioxidant assays compared to the reference (quercetin and vitamin $\mathrm{C}$ ) and $\mathrm{Ni}$ (II)-complex exhibited a promising antioxidant activity.
\end{abstract}

Keywords: Antioxidant activity, Metal complexes, Schiff base ligand.

\section{INTRODUCTION}

Reactive oxygen species and generation of free radicals are inherent part of human metabolism. During the cell death and tissue damage, oxygen-centered free radicals and other reactive oxygen species are continuously produced. So, the organisms are defended by the antioxidant compounds against free radical damage and then due to the human body gains strength to reduce oxidative damage ${ }^{2-4}$. Cells as a result of aerobic metabolism have been producing reactive oxygen species which include oxygen centered radicals $\left(\mathrm{O}_{2}{ }^{\circ}, \mathrm{OH}, \mathrm{NO}\right.$, $\left.\mathrm{RO}^{\circ}, \mathrm{ROO}^{\circ}\right)$ contain one or more unpaired electrons and nonradical molecules (hydrogen peroxide, singlet oxygen, hypochloric acid). On the other hand, due to the organism's normal vital activity, such as phagocytosis, regulation of cell proliferation, intracellular signalization and synthesis of biologically active compounds and ATP are releasing reactive oxygen species as a hazardous components ${ }^{5}$.

In addition, much more activated oxygen species in the forms of superoxide anion $\left(\mathrm{O}^{2-}\right)$ and hydroxyl radical $\left(\mathrm{OH}^{\bullet}\right)$, generated by routine metabolic processes, may cause many diseases such as carcinogenesis, Parkinson's disease, heart disease and cancer,inflammation, atherogenesis and aging in aerobic organisms $\mathrm{s}^{6,7}$.
So the significance of free radicals and reactive oxygen species in the pathogenesis of multifarious diseases has attracted considerable attention. Antioxidants are currently discovered as the drug candidates to counter these diseases. Minor dietary compositions have been seriously considered to combat the pathogenic effects of free radicals and reactive oxygen species ${ }^{8}$.

The realm of bioinorganic chemistry is committed to the research of metallic complexes and their biological employments, containing the design of new drugs that are pretty much popular than those already known. Schiff bases, containing the structure of $>\mathrm{C}=\mathrm{N}$ - (azomethine group), synthesized from condensation reaction of carbonyl group and primary amine, are significant category of compounds in medicinal and pharmaceutical researches ${ }^{9}$. The growing of the area of bioinorganic chemistry has been becoming greater the interest in Schiff base complexes, since lots of these complexes may supply like models for biologically crucial species. Antioxidants have been studied for their activity to preserve organisms and cells from destruction induced by oxidative stress. Considerable attention is being paid in the study of transition metal complexes as drugs on account of their various biological activities ${ }^{10}$. Nowadays, researchers in many disciplines are becoming too much interested in synthesis of new compounds, made up or extracted from natural sources, that may contain active parts 
to prevent or reduce the impression of oxidative effects on cells ${ }^{11-13}$.

The studies on heteroaromatic Schiff base metal complexes have been attracted a great deal of attention since past few decades. Hence, Schiff bases derived from containing a pyridine ring have received considerable interest in the literature due to their important role in biological systems ${ }^{14}$. In the current study, we have prepared new Schiff base ligand derived from 2-acetylpyridine condensation of aspartic acid dimetyl ester and its four metal [Cu (II), $\mathrm{Co}(\mathrm{II}), \mathrm{Ni}(\mathrm{II}), \mathrm{Mn}(\mathrm{II})]$ complexes. Consequently, we have described the synthesis, characterization and antioxidant activities of this ligand and its four metal complexes using FT-IR, ${ }^{1} \mathrm{H}$ NMR, ${ }^{13} \mathrm{C}$ NMR, elemental, ICP-OES, ESI-MS, EPR(ESR), UV-visible spectral analyses.

\section{EXPERIMENTAL}

All of the precursor chemicals and solvents were purchased commercially available reagent grade from Merck, Aldrich or Fluka and used without purification. They were 2-acetylpyridine, 5,5-dimetyl- $N$-oxide pyrroline, 2,2-diphenyl-1picrylhydrazyl radical (DPPH), aspartic acid and thionyl chloride. Methanol, ethanol, chloroform, dichloromethane, $n$-hexane and ethyl acetate used as organic reagent and solvent.

To the characterization of the synthesized ligand (apasp) and its four metal complexes were based on the analysis of NMR, LC-MS, FT-IR, elementel, Melting point and UV/visible spectra. The NMR spectra were recorded on a Bruker $400 \mathrm{MHz}$ spectrometer (Bruker Daltonics $\mathrm{GmbH}$, Switzerland) using dimethyl sulfoxide (DMSO- $d_{6}$ ) and $\mathrm{CDCl}_{3}$ as solvents. IR spectra were recorded on a Perkin-Elmer FT-IR type 1650 spectrophotometer. Elemental analyses were recorded on a Perkin-Elmer 240B micro analyzer.The absorbance was measured at PerkinElmer LAMBDA 850 UV/visible. Melting points were measured on a RY-1 micro melting point apparatus. The electron impact (ESI) mass spectra $(70 \mathrm{eV})$ were obtained on a Perkin-Elmer system. ESR spectra were obtained with a Bruker E-scan spectrometer. All other chemical supplies were of analytical grade and purchased from conventional commercial sources

Synthesis of 2-acetylpyridine dimethyl ester Schiff base ligand"apasp": To a stirred mixture of L-aspartic acid (2g, $15 \mathrm{mmol})$ in methanol $(50 \mathrm{~mL})$, thionyl chloride $(3.15 \mathrm{~mL}, 46$ mmol) was added drop wise in an ice bath and then mixture was stirred for $16 \mathrm{~h}$ at room temperature and solvent was evaoparated to obtain the product which was a white oily solid $^{15}$. The ligand was synthesized by changing the reported procedures $^{16,17}$. To a solution of 2-acetylpyridine e $(1.82 \mathrm{~g}, 15$ $\mathrm{mmol})$ in $50 \mathrm{~mL}$ ethanol, an ethanolic solution $(30 \mathrm{~mL})$ of L-aspartic acid dimethyl ester $(2.76 \mathrm{~g}, 14 \mathrm{mmol})$ was added at the room temperature and was heated to reflux at $80{ }^{\circ} \mathrm{C}$ under $\mathrm{N}_{2}$ atmosphere for $6 \mathrm{~h}$. A few drops of $\mathrm{Et}_{3} \mathrm{~N}$ were added into the reaction medium. At the end of the reaction, solvent was afforded to remove to take the final product, a brown-yellow oil, was dissolved in $70 \mathrm{~mL}$ chloroform and washed successively with distilled water, brine solution and finally again distilled water. The organic phase separated was later dried over anhydrous $\mathrm{MgSO}_{4}$ for $2 \mathrm{~h}$, filtered and solvent was completely evaporated. The yellow oily liquid was obtained as a Schiff base ligand (Scheme-I). (Yield: $2.64 \mathrm{~g}$, about $66 \%$ ). FT-IR $\left(\mathrm{cm}^{-1}\right)$ : 3055, 2953, 1734, 1698, 1617, 1584, 1567, 1465, 1433, 1357, 1110, 984, 779, 730, 589; ${ }^{1} \mathrm{H}$ NMR $\left(\mathrm{CDCl}_{3}, \mathrm{ppm}\right): \delta$, 8.70 (d, 1H, CH=N, C2), 8.04 (s, 1H, CH=C, C5), 7.85 (t, 1H, $\mathrm{CH}=\mathrm{C}, \mathrm{C} 1), 7.48$ (t, 1H, $\mathrm{CH}=\mathrm{C}, \mathrm{C} 6), 3.66-3.75$ (m, 3H, C9, C10), 2.74 (s, 6H, $\left.\mathrm{OCH}_{3}, \mathrm{C} 16, \mathrm{C} 18\right), 2.50$ (s, 3H, $\left.\mathrm{CH}_{3}, \mathrm{C} 19\right)$. ${ }^{13} \mathrm{C} \mathrm{NMR}\left(\mathrm{CDCl}_{3}, \mathrm{ppm}\right): \delta 174\left(\mathrm{C}=\mathrm{O}, \mathrm{Cl}_{3}\right), 171(\mathrm{C}=\mathrm{O}, \mathrm{C} 11)$, 153.50 (C=N, C7), 148, 136,8, 127, 121, 53, 52, 51, 38, 25. The EI-MS: $m / z 265(\mathrm{M}+1)^{+}, 204(\mathrm{M}-60)^{+}, 191(\mathrm{M}-73)^{+}, 173$ $(\mathrm{M}-91)^{+}, 145(\mathrm{M}-119)^{+}, 121(\mathrm{M}-143)^{+}$. Anal. calcd. for $\mathrm{C}_{13} \mathrm{H}_{16} \mathrm{~N}_{2} \mathrm{O}_{4}$ : C, 54.80; H, 6; N, 10.60; found: C, 53.63; H, $5.75 ; \mathrm{N}, 10.30$.

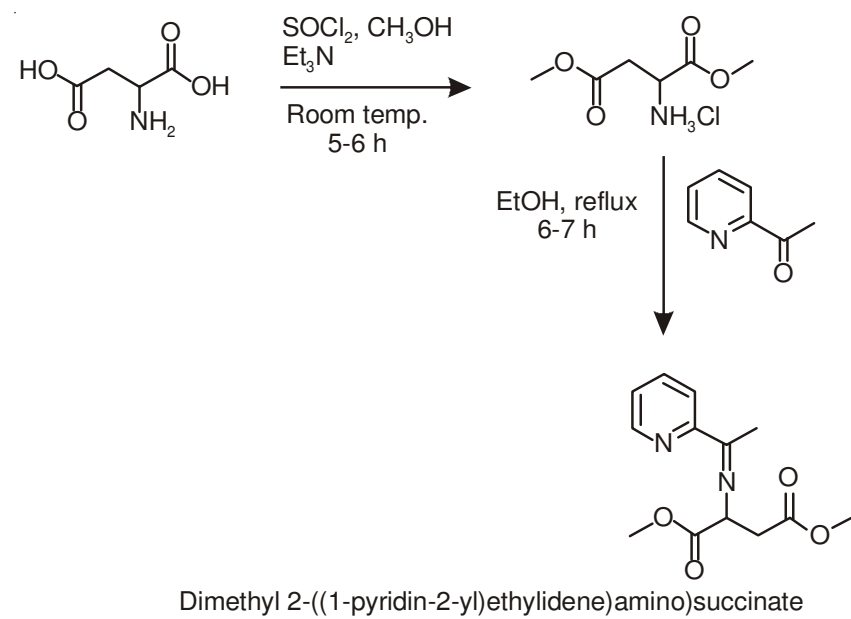

Scheme-I: Schematic representation of the synthesis route of ligand"asasp"

Synthesis of the metal complexes: The following general procedure was used in all cases. The ligand $(0.1 \mathrm{mmol})$ and appropriate metal salt $\left[\mathrm{Cu}(\mathrm{AcO})_{2} \cdot \mathrm{H}_{2} \mathrm{O}, \mathrm{NiCl}_{2} \cdot 6 \mathrm{H}_{2} \mathrm{O}\right.$, $\mathrm{MnCl}_{2} \cdot 4 \mathrm{H}_{2} \mathrm{O}$ and $\left.\mathrm{CoCl}_{2} \cdot 6 \mathrm{H}_{2} \mathrm{O}\right](0.1 \mathrm{mmol})$ were mixed in warm ethanol $(30 \mathrm{~mL})$. The solution was refluxed for $8 \mathrm{~h}$ and filtered while hot. One of them, copper(II) complex, the volume of the filtrate was reduced to $10 \mathrm{~mL}$ and the solution was left standing for crystallization. Others were dissolved in $70 \mathrm{~mL}$ chloroform and washed successively with distilled water, brine solution and finally again distilled water. The organic phase separated was later dried over anhydrous $\mathrm{MgSO}_{4}$ for $1 \mathrm{~h}$, filtered and solvent was completely evaporated ${ }^{18}$. All products were dark colorful, oily liquid, however just only copper(II) complex was obtained in solid form. At final step, copper(II) complex was separated out after overnight cooling processes and dried under lower pressure.

NiL: Brown color, oily liquid (65\%): FT-IR (KBr, $v_{\max }$, $\mathrm{cm}^{-1}$ ): 2099, 1722, 1636, 1601, 1445, 1372, 1314, 1258, 1168, 1099, 1022, 623, 587; Analysis (\%): Found (Calcd.) for $\mathrm{C}_{13} \mathrm{H}_{20} \mathrm{~N}_{2} \mathrm{O}_{6} \mathrm{Ni}$ : C, 34.85 (34.50); H, 4.55 (4.80); N, 6.24 (6.36). UV-visible max: $229 \mathrm{~nm}\left(\lambda_{\max }=15598.66 \mathrm{~L} \mathrm{~mol}^{-1} \mathrm{~cm}^{-1}\right), 270$ $\mathrm{nm}\left(\lambda_{\max }=10946.02 \mathrm{~L} \mathrm{~mol}^{-1} \mathrm{~cm}^{-1}\right)$.

CuL: Dark brown color, solid (70 \%): FT-IR (KBr, $v_{\max }$, $\left.\mathrm{cm}^{-1}\right)$ : 3035, 2978, 1725, 1680, 1557, 1469, 1392, 1335, 1239, 1155, 1023, 779, 673; Analysis (\%): Found (Calcd.) for $\mathrm{C}_{21} \mathrm{H}_{28} \mathrm{~N}_{2} \mathrm{O}_{12} \mathrm{Cu}_{2}$ : C, 45.00 (44.60); H, 4.80 (4.35); N, 5.60 (5.40); UV-visible max: $227 \mathrm{~nm}\left(\lambda_{\max }=18918.9 \mathrm{~L} \mathrm{~mol}^{-1} \mathrm{~cm}^{-1}\right)$, $261 \mathrm{~nm}\left(\lambda_{\max }=18468.32 \mathrm{~L} \mathrm{~mol}^{-1} \mathrm{~cm}^{-1}\right)$. 
MnL: Gray color, oily liquid (68\%): FT-IR (KBr, $v_{\max }$, $\left.\mathrm{cm}^{-1}\right)$ : 3050, 2090, 1716, 1626, 1587, 1513, 1475, 1443, 1403, 1347, 1244, 1096, 1019, 531; Analysis (\%): Found (Calcd.) for $\mathrm{C}_{13} \mathrm{H}_{20} \mathrm{~N}_{2} \mathrm{O}_{6} \mathrm{Mn}$ : C, 35.16 (36.6); H, 4.95 (4.81); N, 6.32 (4.45); UV-visible max: $230 \mathrm{~nm}\left(\lambda_{\max }=14540.4 \mathrm{~L} \mathrm{~mol}^{-1} \mathrm{~cm}^{-1}\right)$, $269 \mathrm{~nm}\left(\lambda_{\max }=9869.4 \mathrm{~L} \mathrm{~mol}^{-1} \mathrm{~cm}^{-1}\right)$.

CoL: Dark olive green color, oily liquid (66 \%): FT-IR $\left(\mathrm{KBr}, v_{\max }, \mathrm{cm}^{-1}\right)$ : 3054, 2097, 1727, 1600, 1597, 1440, 1374, 1308, 1239, 1099, 857, 779, 619; Analysis (\%): Found (Calcd.) for $\mathrm{C}_{13} \mathrm{H}_{20} \mathrm{~N}_{2} \mathrm{O}_{6} \mathrm{Co}$ : C, 3349 (33.10); H, 5.19 (5.10); N, 6.03 (5.86); UV-visible max: $229 \mathrm{~nm}\left(\lambda_{\max }=16699.78 \mathrm{~L} \mathrm{~mol}^{-1} \mathrm{~cm}^{-1}\right)$, $270 \mathrm{~nm}\left(\lambda_{\max }=11814.56 \mathrm{~L} \mathrm{~mol}^{-1} \mathrm{~cm}^{-1}\right)$.

Preparation of ICP-OES Samples: The complexes were prepared in a Berghof MWS-3+ microwave before the ICP analyses were conducted. A suitable amount of the sample, $\mathrm{HNO}_{3}$ and $\mathrm{HCl}$, was added to the DAP60 vessel and suitable oven conditions were applied (pressure, temperature and microwave power). The digested suspensions were filtered and diluted with an appropriate amount of ultra-pure water. Consequently, sample solutions were analyzed by inductively coupled plasma/optical emission spectrometry (ICP/OES) to determine metal content ( $\mathrm{Co}, \mathrm{Cu}, \mathrm{Ni}, \mathrm{Mn})$ (Table-2).

Hydroxyl radical $\left(\mathrm{HO}^{\circ}\right)$ scavenging activity with EPR Method: Hydroxyl radical scavenging activities of synthesized compounds were carried out by the EPR method. EPR assay was based on the competition between the trapping agent and the anti-oxidativeligand and metal complexes. Hydroxyl radical was produced by Fenton reaction, contained $10 \mu \mathrm{L}$ of $3 \mathrm{mM}$ freshly prepared $\mathrm{FeSO}_{4}, 80 \mu \mathrm{L}$ of 0.75 mM EDTA, 15 $\mu \mathrm{L}$ of $1 \mathrm{M}$ DMPO (5,5-dimetyl- $N$-oxide pyrroline), $15 \mu \mathrm{L}$ of $0.5 \mathrm{mM} \mathrm{H}_{2} \mathrm{O}_{2}$ and $30 \mu \mathrm{L}$ of ligand and its metal complexes's solution or solvent for the blank. The final concentrations were $2 \mathrm{mM}$ for all sample's solutions. The EPR measurements were put through at $15 \mathrm{~min}$ of each reaction at room temperature, using a Bruker E-Scan spectrometer, the following spectrometer settings: microwave power of $12.17 \mathrm{~mW}$, field modulation frequency of $86 \mathrm{kHz}$ and a modulation amplitude of $3.06 \mathrm{G}$, number of $\mathrm{x}$ scans 64 , center $^{19}$ field $3472.00 \mathrm{G}$. The inhibition ratio was estimatedby using double integral of signals by employing eqn. 1 :

$$
\text { Inhibition ratio }=\frac{\text { ref }- \text { sample }}{\text { ref }- \text { bg }}
$$

where ref is the reference signal (DPPH+ methanol), sample is the test signal, bg is the background signal and the experiments were conducted in triplicate.

2,2-Diphenyl-1-picrylhydrazyl radical scavenging test using UV-visible spectrophotometer: Free radical scavenging activity of the ligand and its metal complexes was assessed by using the stable 2,2-diphenyl-1-picrylhydrazyl radical as well as former reported procedure ${ }^{20}$. UV-visible spectra were recorded on a Perkin-Elmer Lambda 25 spectrophotometer by using match cells of $1 \mathrm{~cm}$ path length. To conduct DPPH free radical scavenging of synthesized ligand and its four metal complexes, different concentrations of the chemical compounds at the assay were dissolved in methanol to obtain final concentration ranged from 20 to $400 \mu \mathrm{g} / \mathrm{mL}$ to determine radical scavenging activity. $3 \mathrm{~mL}$ of various sample concentrations were added to $1 \mathrm{~mL}$ of $400 \mu \mathrm{g} / \mathrm{mL}$ methanolic solution of DPPH. After a $0.5 \mathrm{~h}$ of incubation at dark, the absorbance was read against a blank at $517 \mathrm{~nm}$. The experiments were carried out in triplicates. The percent of DPPH scavenging activity was measured by using the following equation.

DPPH free radical scavenging activity $=\frac{\mathrm{A}_{0}-\mathrm{A}}{\mathrm{A}_{0}}-100$ $\mathrm{A}_{0}=$ The absorbance of the control reaction (containing all reagents except the test compound); $\mathrm{A}=$ the absorbance of the test sample.

2,2-Diphenyl-1-picrylhydrazyl radical and rhodamine tempo scavenging test with EPR method: The antioxidant activities of Schiff base ligand and its metal complexes were examined on the basis of the scavenging activity of rhodamine tempo (synthesized at lab. condition) and 1,1-diphenyl-2picrylhydrazyl free radical $^{21}$ using ESR spectroscopy ${ }^{22}$. The stock solution of DPPH and Rhodamine tempo were prepared by dissolving $400 \mu \mathrm{g}$ of DPPH in $1 \mathrm{~mL}$ of methanol. The concentration range of tested compounds used for antioxidant activity was from $20 \mu \mathrm{g} / \mathrm{mL}$ to $400 \mu \mathrm{g} / \mathrm{mL}$. To $100 \mu \mathrm{L}$ of methanolic solution of DPPH or Rhodamine tempo $(400 \mu \mathrm{g} / \mathrm{mL})$, $100 \mu \mathrm{L}$ of samples with different concentration ranging from 20 to $400 \mu \mathrm{g} / \mathrm{mL}$ was added.Inhibition ratio was calculated by comparison with a methanol-treated control group. EPR spectra were obtained with a Bruker E-Scan spectrometer using microsampling pipettes at room temperature under the following conditions: modulation frequency, $100 \mathrm{kHz}$; modulation amplitude, $0.197 \mathrm{mT}$; scanning field, $349.7 \mathrm{mT}$; receiver gain; sweep time, $11 \mathrm{~s}$; microwave power, $4 \mathrm{~mW}$; microwave frequency, 9.78 GHz. All spectra were recorded at $15 \mathrm{~min}$. The inhibition percentage was calculated by using the double integral of the signal and by using eqn. 1 and the experiments were conducted in triplicate.

\section{RESULTS AND DISCUSSION}

Infrared spectral studies of Schiff base and its metal complexes: The IR spectrum of ligand showed significant characteristic bands corresponding to the $v(C=O), v(C=N)$, $v(\mathrm{C}=\mathrm{C})$ and $v(\mathrm{O}-\mathrm{C})$ functional groups in the compound. The IR spectra of the complexes also exhibited the characteristic bands of the ligand with the corresponding to shifts due to complexes formation (Table-1). The characteristic stretching bands $[\mathrm{v}(\mathrm{C}=\mathrm{O})]$ of the ligand gave at 1734 and $1698 \mathrm{~cm}^{-1}$, while owing to formation of complexes these bands shift to lower frequencies (Table-1). Therefore, it can be proposed that the complex compound coordination occurs by the carbonyl oxygen. Moreover, A band at $1617 \mathrm{~cm}^{-1}$ was assigned to an azomethine $(\mathrm{C}=\mathrm{N})$ group, it was also shifted to lower values (Table-1). Hence, this indicates that metal coordination involves with the nitrogen of azomethine group on the ligand molecule. Besides, other stretching bands were at $3055-2950 \mathrm{~cm}^{-1}$ related to aromatic $\mathrm{C}-\mathrm{H}$ group in ligand ${ }^{23}$.

${ }^{1} \mathrm{H}$ NMR and ${ }^{13} \mathbf{C}$ NMR spectra studies: The ${ }^{1} \mathrm{H}$ NMR spectra of Schiff base ligand in $\mathrm{CDCl}_{3}$ showed signals of doublet at $8.70 \mathrm{ppm}(\mathrm{d}, 1 \mathrm{H}, \mathrm{C} 2)$, doublet at $8.04 \mathrm{ppm}(\mathrm{d}, 1 \mathrm{H}, \mathrm{C} 5)$, triplets at $7.85 \mathrm{ppm}$ and $7.48(\mathrm{t}, 2 \mathrm{H}, \mathrm{C} 1, \mathrm{C} 6)$ were assigned to the protons of pyridine ring, respectively. The multiple in 3.66- 
TABLE-1

RELEVANT INFRARED FREQUENCIES $\left(\mathrm{cm}^{-1}\right)$ OF THE SCHIFF BASE LIGAND AND ITS METAL COMPLEXES [Cu(II), $\mathrm{Co}($ II), Ni(II), AND Mn(II)]

\begin{tabular}{lccccl}
\hline \multicolumn{1}{c}{ Compound } & $v(\mathrm{C}=\mathrm{N})$ (imine) & $v(\mathrm{C}=\mathrm{O})(1)$ & $v(\mathrm{C}=\mathrm{O})(2)$ & $v(\mathrm{C}=\mathrm{C})$ & \multicolumn{1}{c}{ Others } \\
\hline $\mathrm{L}$ "asasp" & 1617 & 1734 & 1698 & 1584 & $1200,1100,779,730,589$ \\
{$\left[\mathrm{~L}\left(\mathrm{Cu}_{2}(\mathrm{AcO})_{4}\right]\right.$} & 1568 & 1725 & 1686 & 1469 & $1392,779,673,616$, \\
{$\left[\mathrm{L}(\mathrm{Co})\left(\mathrm{H}_{2} \mathrm{O}\right)_{2}\right](2 \mathrm{Cl})\left(2 \mathrm{H}_{2} \mathrm{O}\right)$} & 1597 & 1726 & 1666 & 1440 & $1374,1239,1018,779,619$ \\
{$\left[\mathrm{~L}(\mathrm{Ni})\left(\mathrm{H}_{2} \mathrm{O}\right)_{2}\right](2 \mathrm{Cl})\left(\mathrm{H}_{2} \mathrm{O}\right)$} & 1601 & 1722 & 1636 & 1445 & $1372,1258,623,587$ \\
{$\left[\mathrm{~L}(\mathrm{Mn})\left(\mathrm{H}_{2} \mathrm{O}\right)_{2}\right](2 \mathrm{Cl})\left(\mathrm{H}_{2} \mathrm{O}\right)$} & 1598 & 1716 & 1638 & 1410 & $1244,1019,531$ \\
\hline
\end{tabular}
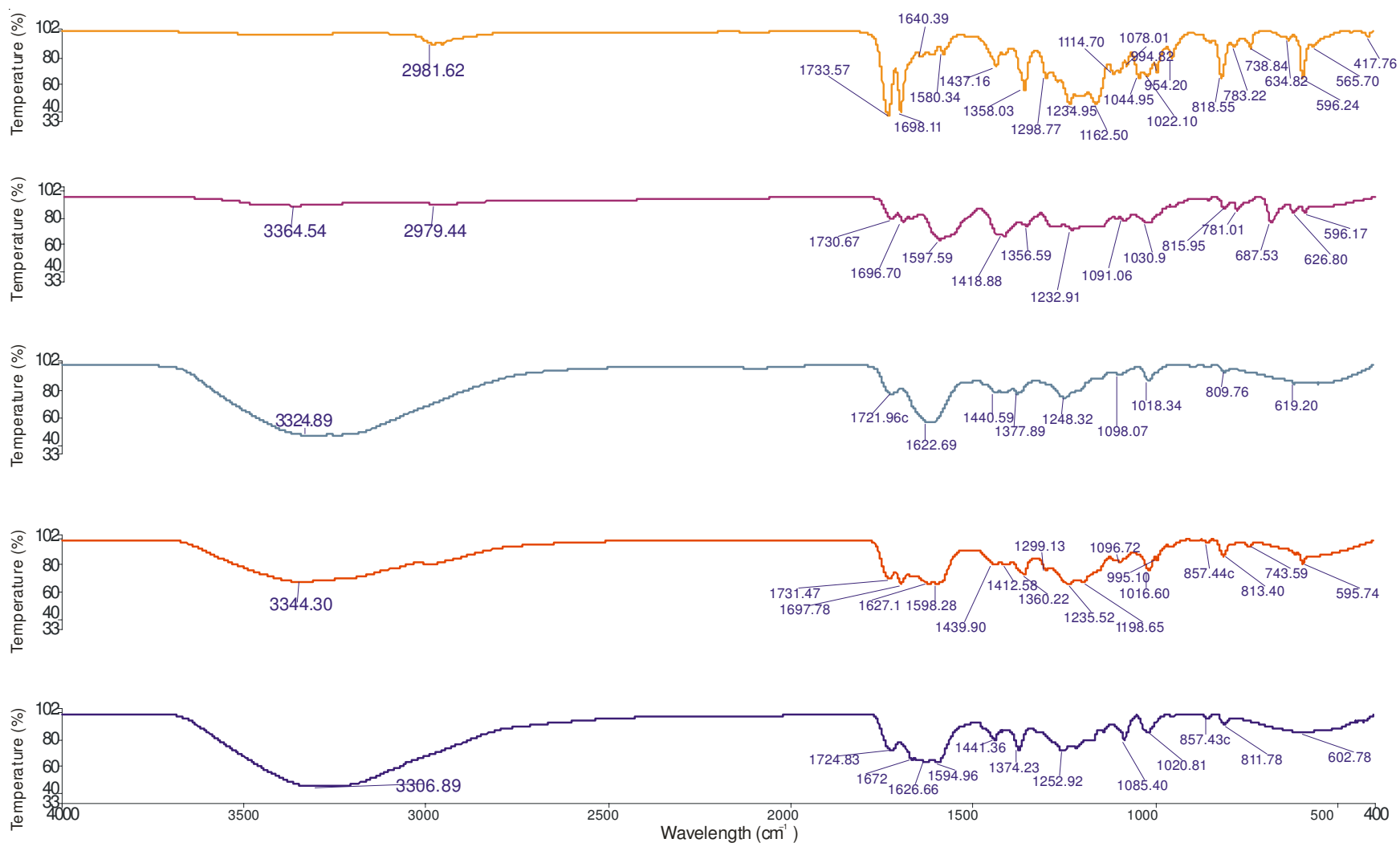

Fig. 1. FT-IR spectra of the Schiff base ligand"asasp" and its four metal complexes

$3.75 \mathrm{ppm}(\mathrm{m}, 3 \mathrm{H}, \mathrm{C} 9, \mathrm{C} 10)$ region were attributed to the protons of aspartic acid dimethyl ester. The singlet band at $2.74 \mathrm{ppm}(\mathrm{s}$, $6 \mathrm{H}, \mathrm{C} 16, \mathrm{C} 18)$ and $2.50 \mathrm{ppm}$ (s, 3H, C19) were also due to the aspartic acid ester moiety. The ${ }^{13} \mathrm{C}$ NMR spectrum consisted of thirteen peaks. Two peaks for $\mathrm{C}=\mathrm{O}(\mathrm{C} 11, \mathrm{C} 13,174,171$ $\mathrm{ppm}$ ), one peak for $\mathrm{CH}=\mathrm{N}$ carbon $(\mathrm{C} 7,153.5 \mathrm{ppm})$, four peaks for pyridine region (148-121 ppm), one peak for $-\mathrm{CH}_{3}(\mathrm{C} 19$, $25 \mathrm{ppm})$ and four peaks for other carbons (C9, C10, C16, C18) were $38,51,52,53 \mathrm{ppm}$, respectively.

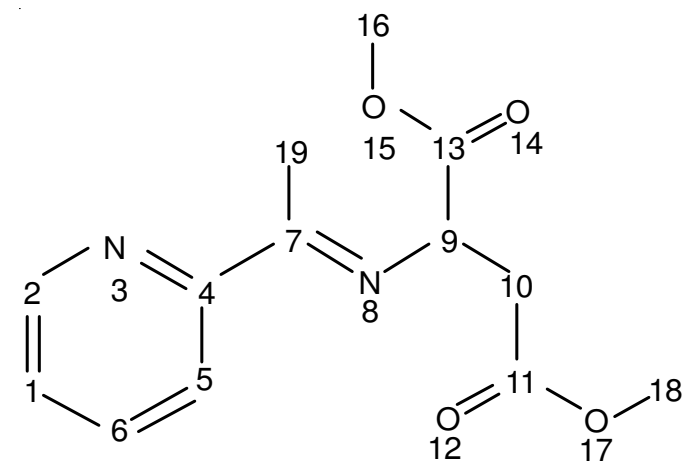

Ligand (asasp)
ESI-Mass spectra, Electronic spectraand Elemental analysisstudies of Schiff base"asasp": Fragments at $\mathrm{m} / \mathrm{z}=$ 265.4 (base peak) was attributed to $\left[\mathrm{C}_{13} \mathrm{H}_{16} \mathrm{~N}_{2} \mathrm{O}_{4}{ }^{+} \mathrm{H}\right]^{+}$. The other molecular ion peaks appeared in the mass spectra was attributed to the fragmentation of the ligand molecule obtained from the rupture of different bonds inside the molecule. In addition, the other $m / z$ peaks such as 204, 191, 173, 145 and 121, respectively were ascertained.

The UV-visible spectrum of the free ligand and its four metal complexes in methanol was shown in Fig. 2. The electronic spectrum of the ligand"asasp" in methanol displayed two major bands at $230\left(\lambda_{\max }=18214.84 \mathrm{~L} \mathrm{~mol}^{-1} \mathrm{~cm}^{-1}\right)$ and $269\left(\lambda_{\max }=\right.$ $\left.12824.4 \mathrm{~L} \mathrm{~mol}^{-1} \mathrm{~cm}^{-1}\right)$. The first band of free ligand in methanol solution was due to $\pi-\pi^{*}$ transition associated with pyridine ring. The second band was attributed to $n-\pi^{*}$ transition related to the azomethine choromophore. By the addition of methanolic solution of metal ions to the ligand medium, the bands responsible for azomethine group were found to be shifted to lower or higher energy region compared to the free ligands transitions confirming the coordination of the ligands to metal ions. In addition, at 455$460 \mathrm{~nm}$ region, absorption bands of $\mathrm{Ni}$ (II) and $\mathrm{Cu}$ (II) complexes were observed as a result of a d-d" transition ${ }^{24}$. 


\begin{tabular}{|c|c|c|c|c|c|c|c|}
\hline \multicolumn{8}{|c|}{$\begin{array}{l}\text { TABLE-2 } \\
\text { ANALYTICAL DATA OF LIGAND “asasp” AND ITS METAL COMPLEXES [Cu(II), Co(II), Ni(II) AND Mn(II)] }\end{array}$} \\
\hline \multirow{2}{*}{ Molecular formula } & \multirow{2}{*}{ m.w. (g/mol) } & \multirow{2}{*}{ Color } & \multirow{2}{*}{ m.p. $\left({ }^{\circ} \mathrm{C}\right)$} & \multicolumn{3}{|c|}{ Elemental analysis (\%): Found (calcd.) } & \multirow{2}{*}{$\begin{array}{l}\text { ICP-OES } \\
\text { (Load./Anal.) }\end{array}$} \\
\hline & & & & $\mathrm{C}$ & $\mathrm{H}$ & $\mathrm{N}$ & \\
\hline $\mathrm{L}^{\prime}$ asasp' $\mathrm{C}_{13} \mathrm{H}_{16} \mathrm{~N}_{2} \mathrm{O}$ & 264.28 & Yellowish & - & $58.6(59.00)$ & $5.78(6.00)$ & $10.3(10.6)$ & - \\
\hline$\left[\mathrm{L}\left(\mathrm{Cu}_{2}(\mathrm{AcO})_{4}\right]\right.$ & 626.10 & Dark Brown & $>80$ & $44.6(45.00)$ & $4.25(4.80)$ & $5.40(5.60)$ & 4 ppm (4.6 ppm) \\
\hline$\left[\mathrm{L}(\mathrm{Co})\left(\mathrm{H}_{2} \mathrm{O}\right)_{2}\right](2 \mathrm{Cl})\left(2 \mathrm{H}_{2} \mathrm{O}\right)$ & 359.00 & Dark Green & - & $33.0(33.49)$ & $5.00(5.19)$ & $5.86(6.03)$ & 4 ppm (3.3 ppm) \\
\hline$\left[\mathrm{L}(\mathrm{Ni})\left(\mathrm{H}_{2} \mathrm{O}\right)_{2}\right](2 \mathrm{Cl})\left(\mathrm{H}_{2} \mathrm{O}\right)$ & 358.00 & Brown & - & $34.5(34.80)$ & $4.80(4.55)$ & $6.36(6.24)$ & $4 \mathrm{ppm}$ (3.91 ppm) \\
\hline$\left[\mathrm{L}(\mathrm{Mn})\left(\mathrm{H}_{2} \mathrm{O}\right)_{2}\right](2 \mathrm{Cl})\left(\mathrm{H}_{2} \mathrm{O}\right)$ & 355.00 & Gray & - & $36.6(35.16)$ & $4.81(4.95)$ & $6.32(6.45)$ & $4 \mathrm{ppm}$ (3.93 ppm) \\
\hline
\end{tabular}

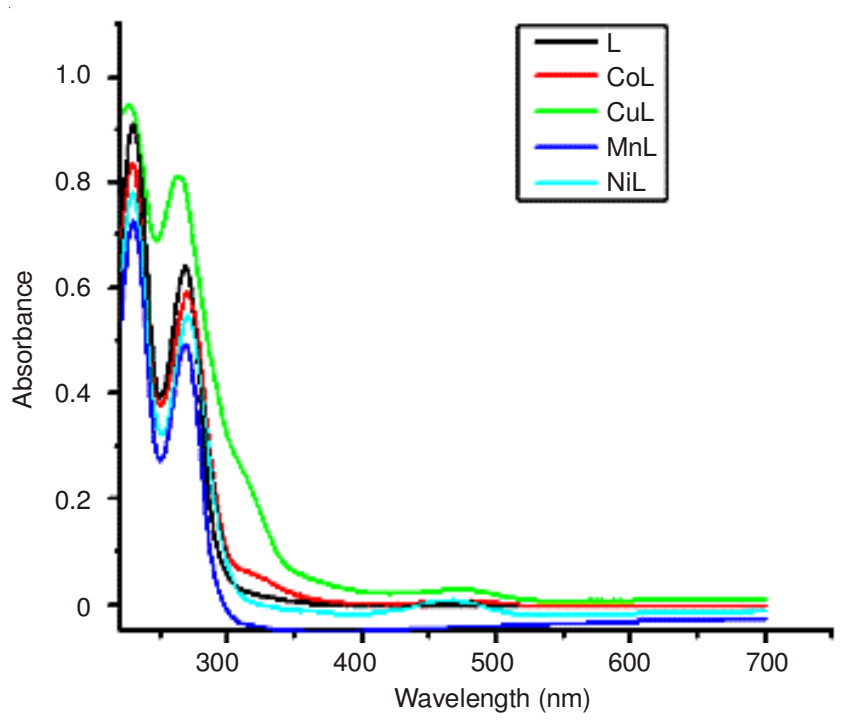

Fig. 2. UV-visible titration of ligand $(50 \mu \mathrm{M}, 100 \mu \mathrm{L})$ with metal ions those are $\mathrm{Cu}(\mathrm{II}), \mathrm{Mn}(\mathrm{II}), \mathrm{Co}(\mathrm{II})$ and $\mathrm{Ni}(\mathrm{II})(1 \mathrm{eq}, 50 \mu \mathrm{M}, 100 \mu \mathrm{L})$

\section{Antioxidant assays}

Hydroxyl radical scavenging activity with EPR: There are significant effects in relation to the hydroxyl radical scavenging capability of ligand and its $\mathrm{Cu}(\mathrm{II}), \mathrm{Ni}(\mathrm{II}), \mathrm{Mn}(\mathrm{II})$ and $\mathrm{Co}(\mathrm{II})$ complexes. Furthermore, vitamin $\mathrm{C}$ and quercetin were used as a control group compared with metal complexes, ligands and metal salts (acetate or chloride) (Fig. 3). While the effective activity was obtained in quercetine application, the lowest activity was determined in metal-salts application. Besides, it was seen among the control groups and ligand/ metal complexes that there was no big radical scavenging activity difference. Even if the quercetin and vitamin $\mathrm{C}$ compare with the ligand and complexes conducted same experiment conditions, it can be speculated that they have reasonable antioxidant activity. In this method, results show that synthesized ligand and its metal complexes have an effective scavenging capacity.

2,2-Diphenyl-1-picrylhydrazyl radical scavenging test with UV-visible: Percentage activity of methanolic solution of ligand and its four metal complexes were studied. Fig. 4 demonstrated that copper(II) complex had pretty much a radical scavenging activity on DPPH. As seen in the Fig. 4, when sample, different concentrations, was added in the DPPH solution, slowly, color of solution which was a deep violet color due to the strong absorption band of DPPH at $517 \mathrm{~nm}$ was changed to yellow. The reaction of DPPH with synthesized compounds was quite fast but slower as compared to these with vitamin $\mathrm{C}$ and quercetin. Other side, the decrease in absorbance values of DPPH was measured in methanol and buffered methanol. 2,2-Diphenyl-1-picrylhydrazyl radical

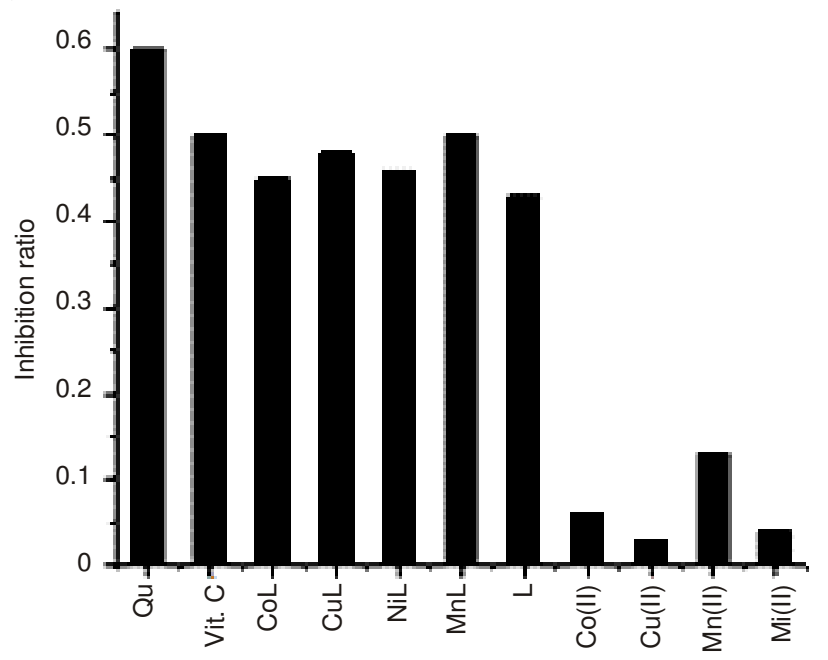

Fig. 3. Scavenging effects of $\mathrm{L}$ and its metal complexes(Cu(II), Co(II), $\mathrm{Ni}(\mathrm{II}), \mathrm{Mn}(\mathrm{II})$ ), metal salts, quercetin and vitamin $\mathrm{C}$ as a control group on hydroxyl radical using EPR

scavenging percent was calculated by comparing the absorbance values of control and test samples. The 2,2-diphenyl-1picrylhydrazyl scavenging activity of ligand, its metal complexes and metal salts were spectrophotmetrically screened and the data obtained were also subjected to the statistical analysis. For this purpose, SPSS 17.00 statistical program was used to determine statistical significance levels by employing one-way ANOVA followed by Duncan multiple range test and the differences between individual averages were considered to be statistically important at $\mathrm{p}<0.05$. Means in the same column by the same letter are not significantly different to the test of Duncan $(\alpha=0.05)$. In order to determine the free radical scavenging activity, different concentration (20, 40, 80, 160, $200,400 \mu \mathrm{g} / \mathrm{mL}$ ) of the ligand, its metal complexes and metal salts were used in comparison with standard antioxidant compounds (quercetine and vitamin C). Samples exhibited higher free radical scavenging activity with increasing concentration except Mn(II) complex and copper(II) salt (Table-3). Furthermore, the metal complexes demonstrated higher activity than the free ligand (asasp) and metal salts but the radical scavenging potent of ligand was much higher than the metal salts. $\mathrm{Ni}(\mathrm{II})$-complex was a promising compound due to the its higher antioxidant activity than the standard antioxidant compounds (quercetine and vitamin C).

2,2-Diphenyl-1-picrylhydrazyl radical and Rhodamine tempo scavenging test with EPR: Herein, the antioxidant activity of the synthesized compound and its metal complexes was investigated in vitro by the DPPH and Rhodamine tempo radical scavenging experiment. Fig. 6 exhibits the radical 

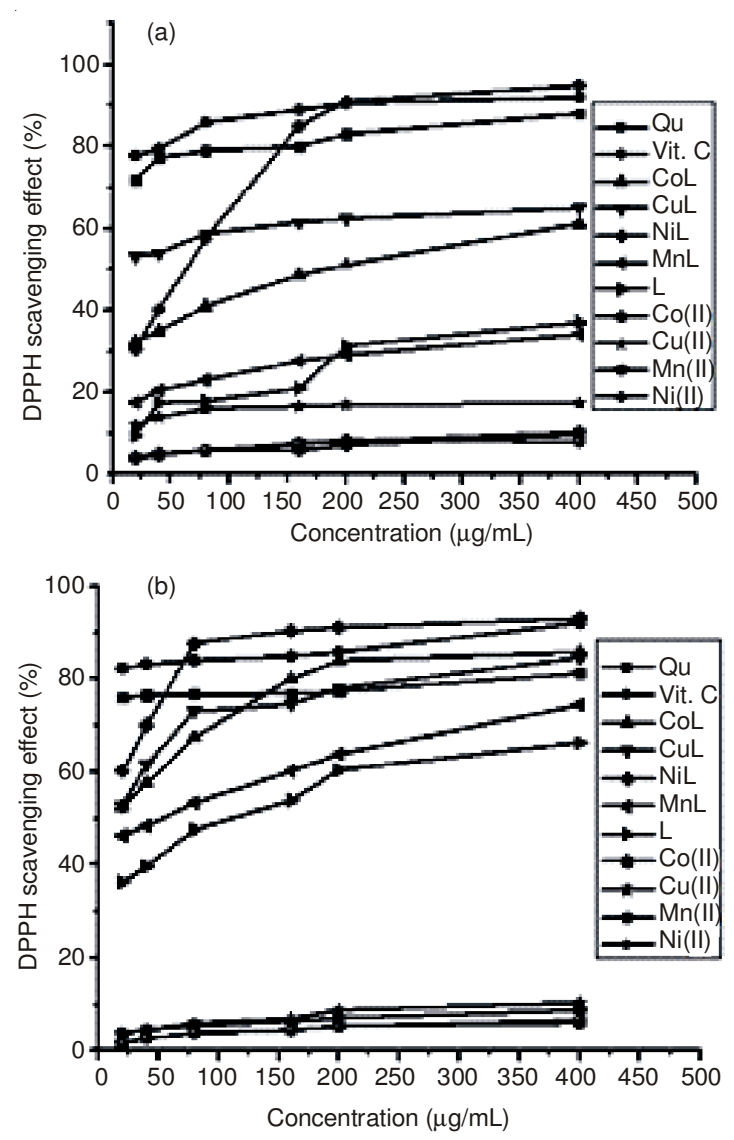

Fig. 4. Scavenging effects of the ligand and its metal complexes( $\mathrm{Cu}(\mathrm{II})$, $\mathrm{Mn}(\mathrm{II}), \mathrm{Ni}(\mathrm{II}), \mathrm{Co}(\mathrm{II}))$ compared with control group vitamin C, Quercetin and metal salts (acetat or chloride) (a), in methanol-acetat buffer $(\mathrm{pH}=5.5)$ (b) on DPPH radical ( UV-visible at $517 \mathrm{~nm}$ )

scevanging activity of ligand "asasp" and its metal complexes against the DPPH which is known to give reliable information concerning the antioxidant activity of sample structures and Rhodamine tempo (synthesized at lab.) radicals by using EPR method. By the meanwhile, due to having an odd electron on it, DPPH can accept an electron or hydrogen free radical. Hence, as seen at the Fig. 5, in the presence of compounds, as a result of $\mathrm{H}$ transfer from these compounds to DPPH moiety the odd electron becomes paired ${ }^{25}$. Upon addition of different concentrations of samples, decreased reference signal of DPPH has demonstrated that ligand and its metal complexes have effective antioxidant activity. The antioxidant and free radical scavenging property of ligand and complexes were investigated extensively at last years. Herein, at Fig. 6, synthesized ligand and metal complexes were determined their antioxidant and radical scavenging effects by using EPR method. To results of

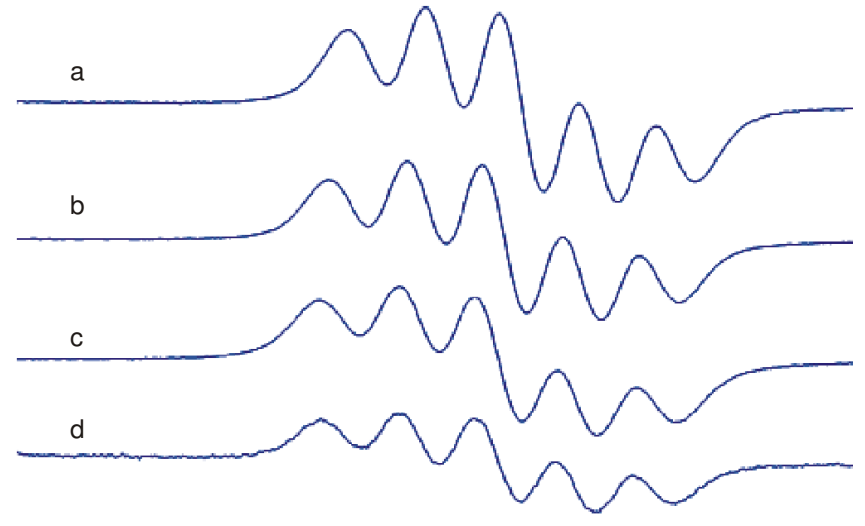

Fig. 5. 2,2-Diphenyl-1-picrylhydrazyl radical ESR spectra by various concentrations of $\mathrm{Cu}$ (II) complex (a) reference signal, DPPH 400 $\mu \mathrm{g} / \mathrm{mL}$; (b) $80 \mu \mathrm{g} / \mathrm{mL}$; (c) $200 \mu \mathrm{g} / \mathrm{mL}$; (d) $400 \mu \mathrm{g} / \mathrm{mL}$
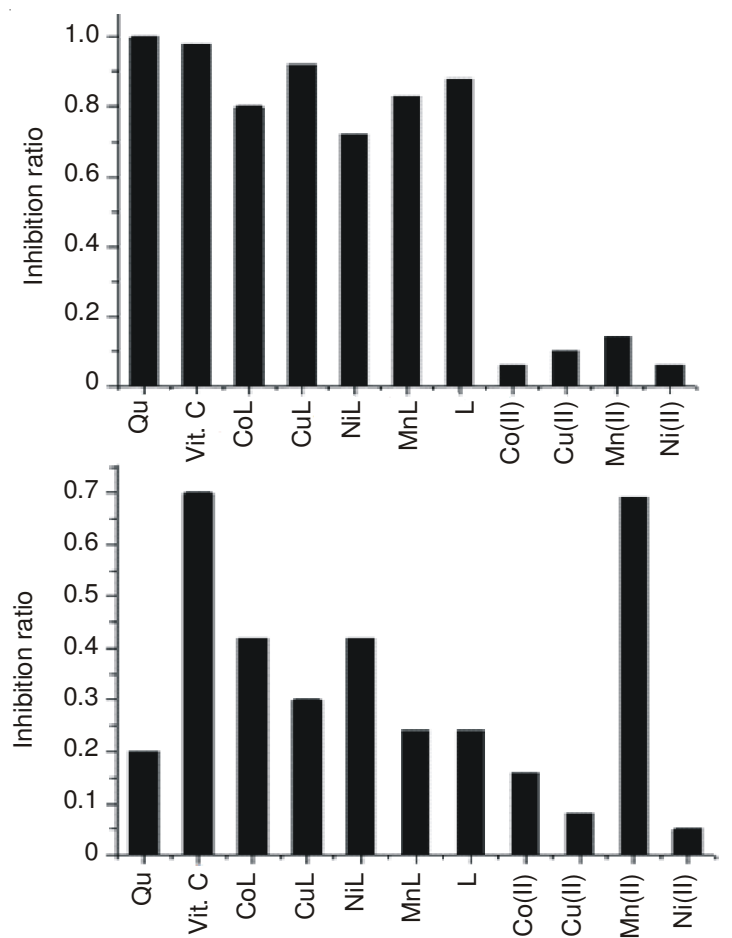

Fig. 6. Scavenging effects of $\mathrm{L}$ and its metal complexes(Cu(II), Co(II), $\mathrm{Ni}(\mathrm{II}), \mathrm{Mn}(\mathrm{II}))$, metal salts, quercetin and vitamin $\mathrm{C}$ as a control group on DPPH and rhodamine tempo radical using EPR $(n=3)$

these experiments, there were some valuable observations about synthesized compounds due to their structural moieties. Hence, it was speculated that these compounds have few functional groups such as imine bond, pyridine ring and carbonyls. Additionally, generally metal complexes have more effective

TABLE-3

DPPH SCAVENGING ACTIVITY OF LIGAND “asasp”, ITS METAL COMPLEXES, METAL SALTS, QUERCETINE AND VITAMIN CBY EMPLOYING ONE-WAY ANOVA FOLLOWED BY DUNCAN MULTIPLE RANGE TEST $(\mathrm{p}<0.05, \alpha=0.05)$.

DPPH scavenging activity of ligand "asasp", its metal complexes, metal salts, quercetine and vitaminC

\begin{tabular}{|c|c|c|c|c|c|c|c|c|c|c|c|}
\hline Concentration & quercetin & Vit. C & $\mathrm{L}$ & $\mathrm{Cu}-\mathrm{L}$ & Mn-L & Co-L & Ni-L & $\mathrm{Cu}$ & $\mathrm{Mn}$ & Co & $\mathrm{Ni}$ \\
\hline 20 & $70,6 \mathbf{a}$ & $78,9 \mathbf{a}$ & $22,24 \mathbf{a}$ & $51,8 \mathbf{a}$ & $31,2 \mathbf{a}$ & $42,1 \mathbf{a}$ & $44,32 \mathbf{a}$ & $7,5 \mathbf{a}$ & $3,82 \mathbf{a}$ & $2,4 \mathbf{a}$ & $2,7 \mathbf{a}$ \\
\hline 40 & $74,35 \mathbf{b}$ & $80,47 \mathbf{a}$ & $27,95 \mathbf{a b}$ & $56,62 \mathbf{a b}$ & $33,9 \mathbf{a}$ & $45,9 \mathbf{a}$ & $54,17 \mathbf{a b}$ & $9,0 \mathbf{a}$ & $4,60 \mathbf{b}$ & $3,4 \mathbf{a b}$ & $3,8 \mathbf{a b}$ \\
\hline 80 & $75,72 \mathbf{b}$ & 83,93 b & 32 abc & 65,33 bc & $37,6 \mathbf{a}$ & 53,8 ab & $71,62 \mathbf{c}$ & $10,93 \mathbf{a}$ & $5,2 \mathbf{c}$ & 4,55 bc & $4,63 \mathbf{b c}$ \\
\hline 160 & 77,55 bc & 86,28 bc & 36,38 abc & $67,23 \mathbf{c}$ & $43,3 \mathbf{a}$ & 64,1 bc & $86,47 \mathbf{c}$ & $11,60 \mathbf{a}$ & $6,82 \mathbf{d}$ & 4,9 cd & 5,8 cd \\
\hline 200 & $79,66 \mathrm{c}$ & $87,67 \mathrm{c}$ & 44,99 bc & $69,7 \mathbf{c}$ & $45,9 \mathbf{a}$ & 67,4 cd & $91,02 \mathbf{d}$ & $12,7 \mathbf{a}$ & $7,5 \mathbf{e}$ & 6,05 de & $6,6 \mathbf{d}$ \\
\hline 400 & $84,95 \mathbf{d}$ & $92,00 \mathbf{d}$ & $50,63 \mathrm{c}$ & $74,05 \mathrm{c}$ & $53,06 \mathbf{a}$ & $75,05 \mathrm{~d}$ & $93,3 \mathbf{d}$ & $13,6 \mathbf{a}$ & $9,3 \mathbf{f}$ & $7,6 \mathbf{e}$ & $7,0 \mathbf{d}$ \\
\hline
\end{tabular}


antioxidant and radical scavenging power. So, at the Fig. 6, it was indicated that the copper(II) complex showed the highest scavenging activity. On the other hand, there was seen the manganese metal ion scavenging of rhodamine tempo radical which had the highest among the others. This strange situation was coming from construction of radical as well as rhodamine tempo was also using as a transition metal ion imaging probe.

\section{Conclusion}

On the basis of the results of the work, we have reported synthesis of a novel Schiff base and its four metal complexes and characterization of ligand and its metal complexes. Further, their antioxidant activities were investigated using UV-visible and EPR against DPPH, rhodamine tempo and hydroxyl radicals. It is indicated that they have generally shown the quite much antioxidant activity against the some oxidative species. In this study, quercetin and vitamin c, well known natural antioxidants were used as a control group. However, if the antioxidant activities are made comparisons between ligand, metal complexes and metal salts, metal complexes generally have much more values than both ligand and metal salts. It can be attributed that the complexes have potent free radical scavenging activity. To the chelation theory, it was speculated that electron density distributed on the complexes may be responsible to display antioxidant activity ${ }^{26}$. Here in, we have especially focused on synthesis of ligand containing pyridine ring and amino acid esters. It was observed that radical scavenging activity of $\mathrm{Ni}$ (II) complex showed much more effect than ligand, other metal complexes and four metal salts. In conclusion, results of this current study encourage us to develop novel design processes for synthesis of compounds for their antioxidant applications as well as for the understanding of antioxidant activity mechanism.

\section{ACKNOWLEDGEMENTS}

The authors are grateful to Assoc. Prof. Dr. Maolin Guo for providing the instrumental analysis facility at Research and Development Centre for University of Massachusetts Dartmouth, MA, USA.

\section{REFERENCES}

1. G.G. Mohamed and Z.H.A. El-Wahab, Spectrochim. Acta A, 61, 1059 (2005).

2. R. Francik, G. Kazek, M. Cegla, M. Stepniewski, Acta Polon. Pharm.Frug Res., 68, 185 (2011)

3. K. Marxen, K.H. Vanselow, S. Lippemeier, R. Hintze, A. Ruser and U.-P. Hansen, Sensors, 7, 2080 (2007).

4. J.-H. Yang, H.-C. Lin and J.-L. Mau, Food Chem., 77, 229 (2002).

5. B. Halliwell and J.M.C. Gutteridge, Free Radical in Biology and Medicine, Clarendon Press, Oxford University Press, Oxford, edn 2 (1989).

6. Y.C. Liu and Z.Y. Yang, J. Inorg. Biochem., 103, 1014 (2009).

7. W. Chen, S. Sun, W. Cao, Y. Liang and J. Song, J. Mol. Struct., 918, 194 (2009).

8. Y. Zhang, B. Zou, Z. Chen, Y. Pan, H. Wang, H. Liang and X.Yi, Bioorg. Med. Chem. Lett., 21, 6811 (2011).

9. D. Sinha, A.K. Tiwari, S. Singh, G. Shukla, P. Mishra, H. Chandra and A.K. Mishra, Eur. J. Med. Chem., 43, 160 (2008).

10. S. Thalamuthu, B. Annaraj and M.A. Neelakantan, Spectrochim. Acta A Mol. Biomol. Spectrosc., 118, 120 (2014).

11. J. Fatimi, J.F. Lagorce, J.L. Duroux, M.L. Chabernaud, J. Buxeraud and C. Raby, Chem. Pharm. Bull. (Tokyo), 42, 698 (1994).

12. N.H. Al-Sha'alan, Molecules, 12, 1080 (2007).

13. M. Alkan, H. Yuksek, Ö. Gürsoy-Kol and M. Calapoglu, Molecules, 13, 107 (2008).

14. M. Asadi, S. Torabi and K. Mohammadi, Monatsh. Chem., 144, 1635 (2013).

15. L. Li, W.-Y. Liu, F. Feng, C.-Y. Wu and N. Xie, Chinese J. Natural Med., 11, 0284 (2013).

16. R. Balamurugan, M. Palaniandavar, H. Stoeckli-Evans and M. Neuburger, Inorg. Chim. Acta, 359, 1103 (2006).

17. M. Hossain, M. Maji, S.K. Chattopadhyay, S. Ghosh and A.J. Blake, Polyhedron, 17, 1897 (1998).

18. H. Adams, R. Bastida, D.E. Fenton, A. Macías, S.E. Spey and L. Valencia, J. Chem. Soc., Dalton Trans., 4131 (1999).

19. K. Zhou, J.-J. Yin and L.L. Yu, Food Chem., 95, 446 (2006).

20. Y. Harinath, D. Harikishore Kumar Reddy, B. Naresh Kumar, C. Apparao and K. Seshaiah, Spectrochim. Acta A, 101, 264 (2013).

21. A. Corona-Bustamante, J.M. Viveros-Paredes, A. Flores-Parra, A.L. Peraza-Campos, F.J. Martínez-Martínez, M.T. Sumaya-Martínez and Á. Ramos-Organillo, Molecules, 15, 5445 (2010).

22. K. Mohammadi, M. Niad and T. Jafari, Spectrochim. Acta A, 122, 179 (2014).

24. A.H. Kianfar, S. Ramazani, R.H. Fath and M. Roushani, Spectrochim. Acta A, 105, 374 (2013).

25. Beena, D. Kumar and D.S. Rawat, Bioorg. Med. Chem. Lett., 23, 641 (2013).

26. P. Datta, A.P. Mukhopadhyay, P. Manna, E.R.T. Tiekink, P.C. Sil and C. Sinha, J. Inorg. Biochem., 105, 577 (2011). 